\title{
Immunomodulation induced by synthetic peptides derived from Staphylococcus aureus protein A
}

\author{
Natalia López-Moratalla ${ }^{\text {a,* }}$, María J. López-Zabalza a, María L. Subirá ${ }^{\text {b }}$, \\ Francisco Borrás-Cuesta ${ }^{c}$, L. Alberto Pérez-Mediavilla ${ }^{a}$, Esteban Santiago ${ }^{a}$ \\ a Department of Biochemistry, University of Navarra, Apartado 273, 31080 Pamplona, Spain \\ ${ }^{b}$ Department of Immunology, University of Navarra, Pamplona, Spain \\ ${ }^{c}$ Centro de Investigaciones Biológicas, University of Navarra, Pamplona, Spain
}

(Received 16 June 1993)

\begin{abstract}
Peptides from 10 to 22 amino acids containing sequences encompassed by Staphylococcus aureus protein A were synthesized. Some of these peptides, when present in cultures of lymphomononuclear cells from healthy donors or from cancer patients (melanoma, breast carcinoma, non-Hodgkin lymphoma and renal cell carcinoma) promoted: (i) changes in the phenotype of the lymphomononuclear population, (ii) stimulation of monocytes (release of IL-1 and TNF- $\alpha$ ), and (iii) an increase in cytotoxicity against K562, Daudi and HT-29 cells. Isolated monocytes responded also to those peptides with a release of IL-1 and TNF $\alpha$ and an increase of cytotoxicity against HT-29 cells. It was found that the active peptides had the following structural pattern: a length of at least 15 amino-acid residues with a proline at position 6, valine, leucine, isoleucine, glycine, alanine or lysine at position 2, and glutamic or aspartic acid at position 11. Replacement of Pro at position 6 with any other residue turned the peptide inactive. Replacement of residues at positions 2 and 11 with amino-acid residues other than those required for activity resulted in compounds with a marked decrease in the immunomodulating properties described, or lacking these properties altogether.
\end{abstract}

Key words: Immunomodulatory peptide; Cytotoxicity; Tumor necrosis factor $\alpha$; Interleukin 1; Lymphomononuclear cell; Monocyte; (Human)

\section{Introduction}

Protein A from Staphylococcus aureus (SpA) [1,2] has a wide variety of immunological properties, such as the stimulation of lymphocyte subpopulations, the release of interferon and natural killer activity [3-7]. In general, exogenous antigens require processing by antigen presenting cells (APC) before their association with MHC proteins to form a complex that can be recognized by specific $T$ cell receptors $[8,9]$. Helper $T$ cells are stimulated by MHC class II molecules which generally present peptides from antigens that have entered B cells or macrophages by endocytosis [10]. T cells do not recognize native protein antigens, unless previously denatured or partially degraded, and subsequently displayed in association with MHC class II (Ia)

\footnotetext{
* Corresponding author. Fax: +34 48175500 .
}

molecules by APC. The pattern of peptide association with various allelic variants of la reflects the pattern of MHC restriction of the immune response [11,12]. The structural requirements for their interactions have been subjected to an intense investigation. Several models have been elaborated to predict $\mathrm{T}$ cell epitopes based on either the presence of amphipathic $\alpha$-helixes [13], amino-acid sequence motifs [14], or structural similarities of MHC core-binding regions on previously identified epitopes [15,16]. However, the binding of an immunodominant peptide to a class II molecule is a necessary, but not sufficient condition to promote an immune response.

We speculated that short synthetic peptides derived from SpA might have similar immunological properties to those exhibited by the native protein, and, if that were the case, that the possible correlation between those properties and the structural features of the active peptides could be established. We show below 
that peptides derived from $\mathrm{SpA}$ are indeed biologically active and that their activity seems to be related to a common structural pattern.

\section{Materials and methods}

\section{Cell source and preparations}

Peripheral blood mononuclear cells from healthy donors or from cancer patients, when indicated, were obtained by leukapheresis, using a Fenwall CS-3000 continuous flow separator (Fenwall Laboratories, Deerfield, IL, USA). Vascular access was obtained with a double central venous catheter. Isolation and purification of monocytes was carried out following the technique described by Bøyum [17].

\section{Cell culture conditions}

Peripheral blood mononuclear cells were cultivated at $2 \cdot 10^{6}$ cells $/ \mathrm{ml}$ in RPMI- 1640 medium supplemented with $2.5 \%$ of autologous serum, $200 \mathrm{mM} \mathrm{L}-$ glutamine, penicillin $(100 \mathrm{U} / \mathrm{ml})$, and streptomycin $(100 \mu \mathrm{g} / \mathrm{ml})$ in humidified atmosphere with $5 \% \mathrm{CO}_{2}$ at $37^{\circ} \mathrm{C}$. Peptides were added at a concentration of 20 $\mu \mathrm{g} / 10^{6}$ cells; rIL-2 at $500 \mathrm{U} / 10^{6}$ cells and $\mathrm{SpA}$ at 20 $\mu \mathrm{g} / 10^{6}$ cells.

\section{Chemical synthesis of the peptides}

The synthesis of the various peptides was carried out by the solid-phase method of Merrifield [18], with the Fmoc modification [19].

\section{Surface markers}

Immunofluorescence studies were performed with a Coulter Epics flow cytometer (Coulter Electronics, Hialeah, FL). The monoclonal antibodies used in this study were: anti-Leu-4 (CD3), Leu-2a (CD8), Leu-11a (CD16), Leu-19 (CD56), Leu-M3 (CD14) and HLA-DR, obtained from Becton-Dickinson Immunocytometry Systems, (Erembodegen, Belgium) and anti-MAC1 (CD11b) from Immunotech (Marseilles, France). All these antibodies were used as conjugates of fluorescein isothiocyanate (FITC). Each assay was accompanied with its appropriate isotype control. $5 \cdot 10^{5}$ cells were incubated in $50 \mu \mathrm{l}$ of PBS- $0.1 \%$ BSA with the monoclonal antibody during $30 \mathrm{~min}$ at $4^{\circ} \mathrm{C}$. After incubation the cells were washed twice with cold PBS-0.1\% BSA. Cells were then fixed in $500 \mu 1$ of formaldehyde in $2 \%$ PBS. Forward angle (FALS) and $90^{\circ}$ light scattering $\left(90^{\circ} \mathrm{LS}\right)$ measurements were recorded. 5000 cells were analyzed for each determination. The percentage of positive cells was determined after substraction of nonspecific labelling events, which, in turn, were evaluated in each measurement with the corresponding isotype control.

\section{Cytokine determinations}

IL-1 and TNF $\alpha$ were measured by the quantitative 'sandwich' enzyme immunoassay technique with commercially available kits (Quantikine, R\&D Systems, Minneapolis, USA).

\section{Cytotoxicity assay}

The $4 \mathrm{~h}{ }^{51} \mathrm{Cr}$ release cytolysis assay [20] was performed with K562 [21] and Daudi [22] cell lines as targets. Target cells $\left(1 \cdot 10^{4}\right)$ were added to serially diluted $\left((50-5) \cdot 10^{4}\right)$ effector cells in RPMI containing $2.5 \%$ autologous serum in round-bottomed microtiter plates. All determinations were carried out in triplicate. The percentage lysis was calculated by the formula ((experimental release - spontaneous release)/ (maximal cpm incorporated - spontaneous release)) $\times$ 100. The spontaneous ${ }^{51} \mathrm{Cr}$ release from cell line targets was always $<10 \%$. Cytotoxicity associated with monocytes was measured following the technique of Meltzer [23] using purified monocytes or lymphomononuclear cells as effector cells, and HT-29 cells from a human adenocarcinoma [24] cultured in monolayer as target cells. HT-29 cells were labelled with $1 \mathrm{mCi} / \mathrm{ml}$ of $\left[{ }^{3} \mathrm{H}\right]$ thymidine when they had a confluence of $50 \%$ and incubated at $37^{\circ} \mathrm{C}$ for $16-18 \mathrm{~h}$. The incubation with the effector cell was carried out at $37^{\circ} \mathrm{C}$ and $5 \%$ $\mathrm{CO}_{2}$.

\section{Results and discussion}

\section{Cytotoxicity induced by synthetic peptides derived from $S p A$}

The amino-acid sequence of Cowan 1 strain staphylococcal protein $(\mathrm{SpA})$ is already well established $[1,2]$. Peptides consisting of 15 amino acids (14 of them reflecting the sequence of the four Fc-binding regions (regions D, A, B and C of SpA as described by Sjödahl [2]) were synthesized. The extra amino acid, always on the carboxyl end, was valine which was added for synthesis convenience. Table 1 shows the ability of synthetic peptides to induce cytotoxicity against tumor cell lines, Daudi and K562, when lymphomononuclear cells were incubated in their presence. IL-2 was used as a reference control.

A close examination of the peptides reveals that all the active structures with regard to cytotoxicity include a proline residue at position 6 and a glutamic acid residue located at the 11 th position. The nature of the amino-acid residues at positions 2 and 3 seems also to be of importance, position 2 being a leucine, isoleucine, valine or a lysine residue, and position 3 preferentially leucine.

These results prompted us to synthesize new peptides introducing amino-acid substitutions in some of the active peptides derived from protein A. Table 2 
Table 1

Cytotoxicity induced by synthetic peptides, derived from $\mathrm{SpA}$ on lymphomononuclear cells from healthy donors

\begin{tabular}{|c|c|c|c|c|}
\hline \multirow{2}{*}{$\begin{array}{l}\text { Peptide } \\
\text { No. }\end{array}$} & \multirow[t]{2}{*}{ Sequence $^{a}$} & \multirow[t]{2}{*}{ Position ${ }^{b}$} & \multicolumn{2}{|c|}{ Cytotoxicity } \\
\hline & & & Daudi & $\bar{K} 562$ \\
\hline 1 & ADAQQNKFNKDQQS & $1-14$ & - & - \\
\hline 2 & QNKFNKDQQSAFYE & $5-18$ & - & - \\
\hline 3 & KDQQSAFYEILNMP & $10-23$ & - & - \\
\hline 4 & ADNNFNKEQQNAFY & $62-75$ & - & - \\
\hline 5 & ADNKFNKEQQNAFY & $120-133$ & - & - \\
\hline 6 & FNKDQQSAFYEILN & $8-21$ & - & - \\
\hline 7 & FNKEQQNAFYEILN & $66-79$ & - & - \\
\hline 8 & FNKEQQNAFYEILH & $182-195$ & - & - \\
\hline 9 & QSAFYEILNMPMLN & $13-26$ & - & - \\
\hline 10 & QNAFYEILNMPNLN & $71-84$ & - & - \\
\hline 11 & QNAFYEILHLPNLN & $129-143$ & - & - \\
\hline 12 & QNAFYEILHLPNLT & $187-200$ & - & - \\
\hline 13 & EILNMPNLNEEQRN & $18-31$ & ++ & ++ \\
\hline 14 & EILHLPNLNEEQRN & $134-147$ & ++ & ++ \\
\hline 15 & EILHLPNLTEEQRN & $192-205$ & ++ & ++ \\
\hline 16 & MPNLNEEQRNGFIQ & $22-35$ & - & - \\
\hline 17 & LPNLNEEQRNGFIQ & $138-151$ & - & - \\
\hline 18 & LPNLTEEQRNGFIQ & $196-209$ & - & - \\
\hline 19 & EEQRNGFIQSLKDD & $27-40$ & - & - \\
\hline 20 & GFIQSLKDDPSQST & $32-45$ & - & - \\
\hline 21 & GFIQSLKDDPSQSA & $90-103$ & - & - \\
\hline 22 & GFIQSLKDDPSVSK & $206-219$ & - & - \\
\hline 23 & SLKDDPSQSTNVLG & $36-49$ & + & + \\
\hline 24 & SLKDDPSQSANLLA & $94-107$ & + & + \\
\hline 25 & SLKDDPSVSKE I LA & $210-223$ & ++ & ++ \\
\hline 26 & PSQSTNVLGEAKKL & $41-54$ & - & - \\
\hline 27 & PSQSANLLAEAKKL & $99-112$ & - & - \\
\hline 28 & PSVSKEILAEAKKL & $215-228$ & - & - \\
\hline 29 & NVLGEAKKLNESQA & $46-59$ & - & - \\
\hline 30 & NLLAEAKKLNESQA & $104-117$ & - & - \\
\hline 31 & NLLAEAKKLNDAQA & $162-175$ & - & - \\
\hline 32 & EILAEAKKLNDAQA & $220-233$ & - & - \\
\hline 33 & KKLNESQAPKADNN & $52-65$ & - & - \\
\hline 34 & KKLNESQAPKADNK & $110-123$ & - & - \\
\hline 35 & KKLNDAQAPKADNN & $168-181$ & - & - \\
\hline 36 & ESQAPKADNNFNKE & $56-69$ & - & - \\
\hline 37 & ESQAPKADNKFNKE & $114-127$ & - & - \\
\hline 38 & DAQAPKADNNFNKE & $172-185$ & - & - \\
\hline 39 & YEI LNMPN LNEEQR & $17-30$ & - & - \\
\hline 40 & FYEI LNNPNLNEEQ & $16-29$ & - & - \\
\hline 41 & QSLKDDPSVSKEIL & $209-222$ & - & - \\
\hline 42 & IQSLKDDPSVSKEI & $208-221$ & - & - \\
\hline 43 & FIQSLKDDPSVSKE & $207-220$ & - & - \\
\hline 44 & FYEILHLPNLNEEQ & $132-145$ & - & - \\
\hline 45 & YEILHLPNLTEEQR & $191-204$ & - & - \\
\hline 46 & FYE I LHLPNLTEEQ & $190-203$ & - & - \\
\hline
\end{tabular}

Peptides were scored for expressed cytotoxicity as follows: ++ , good inducers; + , intermediate inducers; - , non-inducers. Peptide concentration was always $20 \mu \mathrm{g} / 10^{6}$ cells. rIL- 2 at a concentration of $500 \mathrm{U} / 10^{6}$ cells was used as a reference control. Cytotoxicity was determined after 7 days of incubation.

${ }^{a}$ An extra valine residue, not shown, was added at the terminus for synthesis convenience. ${ }^{b}$ Numbering of the amino-acid residue taken from Sjödahl [2].

shows that the replacement of proline by alanine or glycine in the active peptides $13,14,15$ or 25 resulted in inactive peptides. This confirmed the requirement of proline at the indicated position (peptides 47-53). However, the replacement at position 6 by proline in inactive peptides 54 and 55 was unable to render them active. Some other modifications were also introduced in inactive peptides. In peptide 29 (NVLGEAKKLNESQA) Glu at position 5 was replaced by Ala, and Ala at position 6 by Pro. The resulting peptide (peptide 56) was very active with regard to antitumor cytotoxicity against Daudi and K562 cells. Table 3 shows the cytotoxicity induced on lymphomononuclear cells by synthetic peptides resulting from modifications of peptide 56. The results showed that for a peptide of 15 amino acids, the requirements for activity were: proline at position 6 , glutamic acid at position 11 , and leucine, isoleucine or valine at position 2 . With the exception of peptide 25 , in all active peptides tested, position 3 was always leucine. The peptides resulting from the replacement of Val at position 2 of peptide 56 by Lys or a hydrophobic amino-acid residue were still active. However, this activity was rather low. The activity was also greatly reduced if Glu at position 11 was replaced by Asp. The replacement of an amino-acid residue at any position either to the right or to the left of proline at position 6 by proline resulted in inactive peptides.

The non-Fc-binding region $\mathrm{E}$ of SpA contains also a sequence fulfilling the structural pattern of active peptides. The synthetic peptide QVLNMPNLNADQRNV, which contains 14 amino-acid residues of such a sequence plus an extra valine at the $\mathrm{C}$ end, also induced cytotoxicity.

The length of the peptide was also tested. Extended peptides containing the structure of an active peptide were also active. This was the case of peptides DQQSAFYEILNMPNLNEEQR (peptide 81, sequence 11-30 in $\mathrm{SpA}$ ) and NGFIQSLKDDPSVSKEILAEAK (peptide 82, sequence 205-226 in SpA). However, peptides shortened from either the amino or the carboxyl end were inactive (data not shown).

Table 2

Effect of single amino-acid substitutions at position 6 on the cytotoxic activity of synthetic peptides

\begin{tabular}{lllll}
\hline $\begin{array}{l}\text { Peptide } \\
\text { No. }\end{array}$ & Sequence $^{\text {a }}$ & $\begin{array}{l}\text { Derived from } \\
\text { wild peptide }\end{array}$ & \multicolumn{2}{c}{ Cytotoxicity } \\
\cline { 5 - 6 } & & & Daudi & K562 \\
\hline 47 & EILNMANLNEEQRNV & $13(\mathrm{P} \rightarrow \mathrm{A})$ & - & - \\
48 & EILHLANLNEEQRNV & $14(\mathrm{P} \rightarrow \mathrm{A})$ & - & - \\
49 & EILHLANLTEEQRNV & $15(\mathrm{P} \rightarrow \mathrm{A})$ & - & - \\
50 & EILNMGNLLEEQRNV & $13(\mathrm{P} \rightarrow \mathrm{G})$ & - & - \\
51 & SLKDDGSVSKEILAV & $25(\mathrm{P} \rightarrow \mathrm{G})$ & - & - \\
52 & EILHLGNLNEEQRNV & $14(\mathrm{P} \rightarrow \mathrm{G})$ & - & - \\
53 & EILHLGNLTEEQRNV & $15(\mathrm{P} \rightarrow \mathrm{G})$ & - & - \\
54 & YEILHPPNLNEEQRV & $45(\mathrm{~L} \rightarrow \mathrm{P})$ & - & - \\
55 & ADAQQPKFNKDQQSV & $1(\mathrm{~N} \rightarrow \mathrm{P})$ & - & -
\end{tabular}

Peptide concentration was always $20 \mu \mathrm{g} / 10^{6}$ cells. rIL-2 at a concentration of $500 \mathrm{U} / 10^{6}$ cells was used as a reference control. Cytotoxicity was determined after 7 days of incubation.

a In bold: amino-acid replacement at position 6 of the wild peptide. 
Table 3

Cytotoxicity induced on lymphomononuclear cells from healthy donors following amino-acid replacement in the sequence of peptide 56

\begin{tabular}{|c|c|c|c|}
\hline \multirow{2}{*}{$\begin{array}{l}\text { Peptide } \\
\text { No. }\end{array}$} & \multirow[t]{2}{*}{ Sequence ${ }^{a}$} & \multicolumn{2}{|c|}{ Cytotoxicity } \\
\hline & & $\overline{\text { Daudi }}$ & $\mathrm{K} 562$ \\
\hline 56 & NVLGAPKKLNESQAV & ++ & ++ \\
\hline 57 & NVLPAPKKLNESQAV & + & + \\
\hline 58 & NVLGAPKKPNESQAV & + & + \\
\hline 59 & NTLGAPKKLNESQAV & + & + \\
\hline 60 & NCLGAPKKLNESQAV & + & + \\
\hline 61 & NKLGAPKKLNESQAV & + & + \\
\hline 62 & NFLGAPKKLNESQAV & - & - \\
\hline 63 & NMLGAPKKLNESQAV & - & - \\
\hline 64 & NQLGAPKKLNESQAV & - & - \\
\hline 65 & NWLGAPKKLNESQAV & - & - \\
\hline 66 & NSLGAPKKLNESQAV & - & - \\
\hline 67 & NYLGAPKKLNESQAV & - & - \\
\hline 68 & NALGAPKKLNESQAV & + & + \\
\hline 69 & NGLGAPKKLNESQAV & + & + \\
\hline 70 & NVLGAAKKLNESQAV & - & - \\
\hline 71 & NVLGAGKKLNESQAV & - & - \\
\hline 72 & NVLGAPKLLNKSQAV & + & - \\
\hline 73 & NVLGAPKKLNVSQAV & - & - \\
\hline 74 & NVLGAPKKLNDSQAV & + & + \\
\hline 75 & NVLGAPKKLNTSQAV & - & - \\
\hline 76 & NVLGAPKKLNSSQAV & - & - \\
\hline 77 & NVLGMPKKLNESQAV & + & + \\
\hline 78 & NVLGEPKKLNESQAV & - & - \\
\hline 79 & NKLGAPKKLNKSQAV & + & + \\
\hline 80 & NELGAPKKLNVSQAV & - & - \\
\hline
\end{tabular}

Peptide concentration was always $20 \mu \mathrm{g} / 10^{6}$ cells. rlL-2 at a concentration of $500 \mathrm{U} / 10^{6}$ cells was used as a reference control. Cytotoxicity was determined after 7 days of incubation.

a In bold: amino-acid replacement respect to wild peptide 56.

Table 4 shows the cytotoxicity induced by the most active peptides as well as that induced by SpA or IL-2. The cytotoxicity induced by the synthetic peptides against K562 cells was similar to that induced by IL-2 or SpA. The activity against Daudi cells was slightly lower in the case of the synthetic peptides. SpA and active peptides also induced cytotoxicity against HT-29
Table 4

Peptide-induced cytotoxic activity against K562, Daudi and HT-29 target cells

\begin{tabular}{lccl}
\hline Product tested & \multicolumn{2}{l}{ Cytotoxic activity } \\
\cline { 2 - 3 } & \multicolumn{2}{l}{$\begin{array}{l}\text { (\% chromium release) } \\
\end{array}$} & $\begin{array}{l}\left(\%\left[{ }^{3} \mathrm{H}\right] \text { thymidine }\right. \\
\text { release })\end{array}$ \\
\cline { 2 - 3 } & Daudi & K562 & HT-29 \\
\hline Medium & $9 \pm 3$ & $19 \pm 5$ & $27 \pm 5$ \\
Peptide No. 56 & $68 \pm 6$ & $63 \pm 8$ & $62 \pm 6$ \\
Peptide No. 13 & $62 \pm 8$ & $62 \pm 7$ & $59 \pm 5$ \\
Peptide No. 25 & $58 \pm 9$ & $59 \pm 9$ & $57 \pm 5$ \\
Peptide No. 81 & $56 \pm 6$ & $58 \pm 7$ & $58 \pm 6$ \\
Inactive peptide No. 2 & $10 \pm 4$ & $12 \pm 8$ & $29 \pm 4$ \\
rlL-2 & $80 \pm 9$ & $70 \pm 6$ & n.d. \\
SpA & $74 \pm 9$ & $68 \pm 7$ & $67 \pm 5$ \\
IFN $\gamma$ & n.d. & n.d. & $70 \pm 5$ \\
\hline
\end{tabular}

Lymphomononuclear cells were obtained from five different healthy donors. Results represent mean \pm S.E. SpA concentration was 20 $\mu \mathrm{g} / 10^{6}$ cells. Peptide concentration was always $20 \mu \mathrm{g} / 10^{6}$ cells. rIL-2 $\left(500 \mathrm{U} / 10^{6}\right.$ cells $)$ or IFN $\gamma\left(100 \mathrm{U} / 10^{6}\right.$ cells $)$ were used as reference controls. Cytotoxicity was determined after 7 days of incubation. Effector-to-target cell ratio was 50:1 for K562 and Daudi cells, and 20:1 for HT-29 cells. n.d., not determined.

cells, reaching values similar to those obtained with IFN $\gamma$ which was used as positive control.

\section{Phenotypes of lymphomononuclear cells after peptide stimulation}

Surface markers in the cell populations after incubation in the presence of the active peptides were also studied. Table 5 shows the results obtained together with those corresponding to IL-2 or SpA. The percentage of CD3 and CD8 remained constant in the different samples. However, the proportion of cells expressing markers $\mathrm{CD} 11 \mathrm{~b}$ (NK, monocytes and macrophages) and CD14 (monocytes and macrophages) increased in the presence of $\mathrm{SpA}$ or active peptides. The percentage of these markers remained unaltered in populations incubated in the presence of inactive control

Table 5

Phenotypes of lymphomononuclear cells after peptide activation

\begin{tabular}{llllrlr}
\hline Product tested & \multicolumn{2}{l}{ Cells expressing surface markers (\%) } & & \\
\cline { 2 - 6 } & CD3 & CD8 & CD11b & CD14 & CD16 & CD56 \\
\hline Medium & $59 \pm 3$ & $17 \pm 2$ & $14 \pm 4$ & $9 \pm 1$ & $11 \pm 5$ & $6 \pm 2$ \\
Peptide No. 56 & $60 \pm 1$ & $17 \pm 1$ & $23 \pm 5$ & $17 \pm 4$ & $22 \pm 7$ & $18 \pm 6$ \\
Peptide No. 13 & $58 \pm 2$ & $18 \pm 2$ & $24 \pm 3$ & $18 \pm 3$ & $22 \pm 6$ & $17 \pm 5$ \\
Peptide No. 25 & $59 \pm 3$ & $17 \pm 2$ & $23 \pm 4$ & $18 \pm 3$ & $21 \pm 5$ & $18 \pm 5$ \\
Peptide No. 81 & $58 \pm 3$ & $18 \pm 2$ & $21 \pm 3$ & $17 \pm 4$ & $21 \pm 6$ & $17 \pm 5$ \\
Peptide No. 2 & $60 \pm 2$ & $17 \pm 2$ & $13 \pm 4$ & $9 \pm 2$ & $12 \pm 4$ & $6 \pm 2$ \\
rIL-2 & $59 \pm 3$ & $19 \pm 2$ & $13 \pm 2$ & $6 \pm 1$ & $23 \pm 4$ & $25 \pm 3$ \\
SpA & $60 \pm 3$ & $18 \pm 1$ & $23 \pm 4$ & $16 \pm 2$ & $22 \pm 5$ & $20 \pm 4$
\end{tabular}

Lymphomononuclear cells were obtained from five different healthy donors. Results represent mean \pm S.E. SpA concentration was $20 \mu \mathrm{g} / 10^{6}$ cells. Peptide concentration was always $20 \mu \mathrm{g} / 10^{6}$ cells. rIL-2 at a concentration of $500 \mathrm{U} / 10^{6}$ cells was used as a reference control. Phenotypes were determined after 7 days of incubation. 
Table 6

Release of Interleukin-1 and Tumour Necrosis Factor $\alpha$ following addition of cytotoxic peptides or control substances

\begin{tabular}{lccc}
\hline Product tested & \multicolumn{2}{l}{ Factor release } & \\
\cline { 2 - 4 } & $\begin{array}{l}\text { IL-1 } \\
\left(\mathrm{pg} / 10^{6} \text { cells }\right)\end{array}$ & $\begin{array}{l}\text { TNF } \alpha \\
\left(\mathrm{U} / 10^{6} \text { cells }\right)\end{array}$ & $\begin{array}{l}\text { TNF } \alpha \\
\text { + anti-TNF } \alpha\end{array}$ \\
\hline Medium & 12 & 4 & 4 \\
Peptide No. 56 & 68 & 89 & 16 \\
Peptide No. 13 & 62 & 65 & 12 \\
Peptide No. 25 & 39 & 63 & 10 \\
Peptide No. 81 & 39 & 71 & 12 \\
Peptide No. 2 & 5 & 7 & 6 \\
LPS & 150 & - & - \\
PMA & - & 540 & 17 \\
IL-2 & 5 & 5 & 6 \\
SpA & 84 & 143 & 20 \\
\hline
\end{tabular}

Lymphomononuclear cells were obtained from five different healthy donors. Results represent mean \pm S.E.SpA concentration was 20 $\mu \mathrm{g} / 10^{6}$ cells. Peptide concentration was always $20 \mu \mathrm{g} / 10^{6}$ cells; rIL-2, $500 \mathrm{U} / 10^{6}$ cells; LPS $10 \mu \mathrm{g} / \mathrm{ml}$; PMA (100 nM). Incubation time, $24 \mathrm{~h}$.

peptides, or in the presence of IL-2. On the contrary, the expression of CD56 (NK and LAK) was higher in cells incubated in the presence of IL-2, than in the presence of SpA or active peptides. CD16 (neutrophils, monocytes and NK) was elevated in all cell populations with respect to the incubated controls.

\section{Release of interleukin-1 and TNF $\alpha$ induced by synthetic} peptides

In order to ascertain the possible stimulation of monocytes, IL-1 and TNF $\alpha$ were determined in the supernatants after $24 \mathrm{~h}$ of incubation. The results of Table 6 clearly show that both cytokines were released by cells incubated in the presence of either $\mathrm{SpA}$ or the active peptides. As expected, no increase was observed in the supernatants from cells incubated in the pres- ence of IL-2. Lipopolysaccaride (LPS) and phorbol myristate acetate (PMA) were used as positive controls. The nature of TNF $\alpha$ released was also confirmed with anti-TNF $\alpha$ antibody. Preliminary results show also that isolated monocytes incubated in the presence of active peptides responded with the production of IL-1 and TNF $\alpha$ in a time-dependent fashion (data not shown).

Cytotoxicity induced by active peptides on lymphomononuclear cells from cancer patients

The response to immunmodulating peptides was also studied in lymphomononuclear cells from cancer patients. Table 7 shows that peptides 13, 25 and 56, but not peptide 2 , used as a control, induced an increase in cytotoxicity of these cells against K562 and Daudi cells. The values were lower than those elicited by IL-2. The changes of surface markers were similar to those observed with cells obtained from healthy donors (data not shown).

\section{Cytotoxicity induced by active peptides on isolated mono- cytes}

Isolated monocytes incubated for 5 days in the presence of $\mathrm{SpA}$ or active peptides exhibited a cytotoxicity against HT-29 cells higher than those incubated in the presence of an inactive control peptide (Table 8). The optimum effector-to-target cell ratio was $2: 1$.

In conclusion, the results clearly show that a number of synthetic peptides can induce cytotoxicity against cells of tumoral lines K562 and Daudi cells (Tables 1-4). The active peptides have a number of features which can be summarized in the following pattern:

$$
\begin{aligned}
& R_{1}-a a_{1}-a a_{2}-a a_{3}-a a_{4}-a a_{5}-a a_{6}-a a_{7}-a a_{8}-a a_{9}-a a_{10}-a a_{11}-a a_{12^{-}} \\
& a a_{13}-a a_{14}-a a_{15}-R_{2}
\end{aligned}
$$

Table 7

\begin{tabular}{|c|c|c|c|c|c|c|c|}
\hline \multirow[t]{3}{*}{ Patients } & \multicolumn{7}{|c|}{ Product tested } \\
\hline & \multirow[t]{2}{*}{ Medium } & \multirow[t]{2}{*}{ IL-2 } & \multirow[t]{2}{*}{$\overline{\mathrm{SpA}}$} & \multicolumn{4}{|l|}{ Peptide } \\
\hline & & & & No. 13 & No. 56 & No. 25 & $\overline{\text { No. } 2}$ \\
\hline \multicolumn{8}{|l|}{ (a) } \\
\hline A & 12 & 58 & 42 & 21 & 26 & 19 & 12 \\
\hline B & 7 & 46 & 56 & 49 & 44 & 52 & 12 \\
\hline $\mathrm{C}$ & 32 & 60 & 68 & 46 & 50 & 56 & 29 \\
\hline $\mathrm{D}$ & 6 & 88 & 56 & 39 & 41 & 48 & 12 \\
\hline \multicolumn{8}{|l|}{ (b) } \\
\hline A & 3 & 98 & 67 & 40 & 58 & 50 & 6 \\
\hline B & 14 & 38 & 41 & 29 & 32 & 40 & 9 \\
\hline $\mathrm{C}$ & 21 & 48 & 61 & 36 & 46 & 43 & 18 \\
\hline $\mathrm{D}$ & 14 & 38 & 41 & 29 & 32 & 40 & 9 \\
\hline
\end{tabular}

Cytotoxicity induced by synthetic peptides on lymphomononuclear cells from cancer patients

SpA concentration was $20 \mu \mathrm{g} / 10^{6}$ cells. Peptide concentration was always $20 \mu \mathrm{g} / 10^{6}$ cells. rIL-2 at a concentration of $500 \mathrm{U} / 10^{6}$ cells was used as a reference control. Cytotoxicity was determined after 7 days of incubation. Effector cell/Target cell ratio was $50 / 1$. The percentage of Chromium release of top (a) and bottom (b) panels were obtained against K562 and Daudi cells, respectively.

Patients: A, melanoma (stage III); B, non-Hodgkin lymphoma; C, breast carcinoma; D, renal cell carcinoma. 
Table 8

Cytotoxicity induced by synthetic peptides on isolated monocytes against HT-29 cells

\begin{tabular}{ll}
\hline Product tested & $\begin{array}{l}\text { Cytotoxic activity } \\
\left(\%\left[{ }^{3} \mathrm{H}\right] \text { thymidine release }\right)\end{array}$ \\
\hline Medium & $20 \pm 3$ \\
Peptide No. 56 & $60 \pm 4$ \\
Peptide No. 13 & $56 \pm 5$ \\
Peptide No. 25 & $58 \pm 6$ \\
Peptide No. 81 & $50 \pm 4$ \\
Inactive peptide No. 2 & $20 \pm 4$ \\
SpA & $62 \pm 6$ \\
IFN $\gamma$ & $73 \pm 5$ \\
\hline
\end{tabular}

Monocytes were obtained from five different healthy donors. Results represent mean \pm S.E. SpA concentration was $20 \mu \mathrm{g} / 10^{6}$ cells. Peptide concentration was always $20 \mu \mathrm{g} / 10^{6}$ cells. IFN $\gamma\left(100 \mathrm{U} / 10^{6}\right.$ cells) was used as reference control. Cytotoxicity was determined after 5 days of incubation. Effector-to-target cell ratio was $2: 1$.

where $\mathrm{aa}_{6}$ must be Pro, $\mathrm{aa}_{2}$ can be Val, Ile, Leu, Gly, Ala or Lys, and $\mathrm{aa}_{11}$ can be Glu or Asp.The activity of the peptides is maintained if $R_{1}=H$ and $R_{2}=O H$, or if $\mathbf{R}_{1}$ or $\mathbf{R}_{2}$ are longer peptide chains as the ones found in $\mathrm{SpA}$.

The cytotoxicity seems to be mediated by NK, LAK and monocytes as suggested by the cell markers (Table 5); effect on K562 cells (NK dependent), Daudi (LAK and NK dependent) and HT-29 (monocyte dependent); and the release of IL-1 and TNF $\alpha$ (Table 6). Zembala et al. [25] have proposed that the endogenous production of TNF $\alpha$ is possibly involved in the enhancement of antigen presentation by monocytes in an autocrine fashion. The TNF $\alpha$ release induced by the active peptides discussed above could be an important step in the immunopotentiating effects observed.

These results allow also to hypothesize that the stimulation of the different cells involved in the response induced by the active peptides described could have been initiated through monocytes acting as APC.

Cytotoxicity against K562 and Daudi cells was also stimulated by the active peptides in lymphomononuclear cells from a number of cancer patients (Table 7). These results suggest the possibility of using these peptides as a potential cancer therapy.

\section{Acknowledgements}

The skillful technical assistance of Adela Bezunartea is gratefully acknowledged. This work was supported in part by Fundación Echebano.

\section{References}

[1] Uhlén, M., Guss, B., Nilsson, B., Gatenbeck, S., Philipson, L. and Lindberg, M. (1984) J. Biol. Chem. 259, 1695-1702.

[2] Sjödahl, J. (1977) Eur. J. Biochem. 73, 343-351.

[3] Schuurman, R.K.B., Gelfand, E.W. and Dosch, H.M. (1980) J. Immunol. 125, 820-826.

[4] Rutliff, T.L. (1981) Cell Immunol. 57, 1-12.

[5] Forsgren, A., Svedjelund, A. and Wigzell, H. (1976) Eur. J. Immunol. 6, 207-213.

[6] Ringden, O. and Rynnell-Dagoo, B. (1978) Eur. J. Immunol. 8, $47-52$.

[7] Sakane, T. and Green, J. (1978) J. Immunol. 120, 302-311.

[8] Unanue, E.R. and Allen, P.M. (1987) Science 236, 551-557.

[9] Allen, P.M., Babbitt, B.P. and Unanue, E.R. (1987) Immunol. Rev. 98, 171-187.

[10] Germain, R.N. (1986) Nature 322, 657-682.

[11] Babbitt, B.P., Allen, P.M., Matsueda, G., Haber, E. and Unanue, E.R. (1985) Nature 317, 359-361.

[12] Buus, S., Sette, A., Colon, S.M., Miles, C. and Grey, H.M. (1987) Science 235, 1353-1358.

[13] Margalit, H., Spouge, J.L., Cornette, J.L., Cease, K.B., DeLisi, C. and Berzofsky, J.A. (1987) J. Immunol. 138, 2213-2229.

[14] Rothbard, J.B. (1986) Ann. Inst. Pasteur Virol. 137E, 518.

[15] Sette, A., Buus, S., Appella, E., Smith, J.A., Chesnut, R., Miles, C., Colon, S.M. and Grey, H.M. (1989) Proc. Natl. Acad. Sci. USA $86,3296-3300$.

[16] Guillet, J.G., Hoebke, J., Lengagne, R., Tate, K., BorrasHerrera, F., Strosberg, A.D. and Borras-Cuesta, F.(1991) J. Mol. Recogn. 4, 17-25.

[17] Bøyum, A. (1983) Scand. J. Immunol. 17, 429-436.

[18] Merrifield, R.B. (1963) J. Am. Chem. Soc. 85, 2149-2155.

[19] Atherton, E., Logan, J.C. and Sheppard, C.R. (1981) J. Chem. Soc. Perkin Trans. 1, 538-546.

[20] Nair, M.P.N., Kronfol, Z.A. and Schwartz, S.A. (1990) Clin. Immunol. Immunopathol. 54, 395-409.

[21] Ortaldo, J.R., Oldman, R.K., Cannon, G.C. and Herberman, R.B. (1977) J. Natl. Cancer Inst. 59, 77-82.

[22] Klein, E., Klein, G., Nadkarni, J.S., Nadkarni, J.J., Wigzell, H. and Clifford, P. (1968) Cancer Res. 28, 1300-1310.

[23] Meltzer, M.S. (1981) in Manual of Macrophage Methodology (Herscowitz, H.B., Holden, H.T., Bellanti, J.A. and Ghaffer, A., eds.), pp. 329-336. Marcel Dekker, New York.

[24] Fogh, J., Trempe, G. (1975) in Human Tumor "in vitro" (Fogh, J., ed.), pp. 115-119, Plenum Press, New York.

[25] Zembala, M., Kowalczyk, D., Pryjma, J., Ruggiero, I., Mytar, B., Klysik, J. and Stec, W.J. (1990) Int. Immunol. 2, 337-342. 